\title{
Position of Scientific Oncological Societies Towards Biosimilar Antibodies
}

\author{
Bernhard Wörmann Marianne Sinn \\ Deutsche Gesellschaft für Hämatologie und Onkologie (DGHO), Berlin, Germany
}

Keywords

Antibodies · Biosimilars · Oncological societies

\section{Abstract}

First biosimilars of monoclonal antibodies have recently been approved in oncology. Biosimilars enable economic competition, alleviate the financial burden for insurances, and may facilitate access to these drugs in low-income countries. Biosimilars are not completely identical to the original drug. The approval of biosimilars is only partially based on results of randomized clinical studies. In the introduction phase of new biosimilars, this can lead to uncertainties for patients and physicians. Based on the current clinical data and experiences, biosimilars of monoclonal antibodies in oncology show no significant differences in pharmacokinetics, efficacy, and safety in comparison to the patented originals. Scientific medical societies recommend the use of biosimilar monoclonal antibodies and support switching in long-term treatments. However, the use of biosimilars for off-label indications requires additional attention towards efficacy and safety. Active counselling of the patient by the treating physician is the most important step in the informed consent process, especially when switching from an original to a biosimilar. Careful documentation of the prescribed drug and enhanced pharmacovigilance are recommended for the use of biosimilars.

๑) 2019 S. Karger AG, Base

\section{Biosimilars in Oncology}

History and Background

Looking at the current speed of innovation in oncology, biosimilars already have somewhat of a history. Dis- cussions on the similarity of biopharmaceuticals started when the patents of the first generation of DNA-derived drugs expired 15-20 years ago. Proposed terms for this new class of drugs were 'biogenerics', 'generic biologics', 'second-entry biologics', 'follow-on biologics', 'subsequent entry biologics', or 'biosimilars'. Finally, the term 'biosimilars' gained general acceptance.

Biopharmaceuticals are distinct form classical chemical drugs. They are larger and have a complex 3-dimensional structure, further characterized by glycosylation and other posttranslational modifications. The production requires living organisms. In their 'Guideline on similar biological medicinal products', the European Medicines Agency (EMA) defines biosimilars as biological drugs that contain the active substance of a previously approved original biological drug. Similarity to the reference products must be demonstrated on the basis of a comprehensive comparison containing quality criteria, biological activity, safety, and efficacy [1]. The World Health Organization (WHO) has recently updated their 'Guidelines on evaluation of monoclonal antibodies as similar biotherapeutic products (SBPs)'. A special focus is the 'comparability exercise' in addition to rigorous quality criteria for the production of biosimilars [2].

The first biosimilars in oncology were the antineoplastic cytokines interferon- $\alpha 2$ and interleukin-2, shortly followed by the supportive cytokines erythropoietin in 2007 and granulocyte-colony stimulating factor (G-CSF) in 2008 [3]. Acceptance increased gradually, but also the awareness of potential risks. Biosimilars may elicit an immune response including neutralizing antibodies. In one example, immune response against an erythropoietin-alpha drug led to the induction of several cases of pure red cell aplasia [4].

\section{KARGER}

(C) 2019 S. Karger AG, Basel 
Table 1. Monoclonal antibodies in oncology (October 2018)

\begin{tabular}{llll}
\hline Substance & $\begin{array}{l}\text { Approved } \\
\text { in Germany }\end{array}$ & $\begin{array}{l}\text { Approved } \\
\text { after 2010 }\end{array}$ & $\begin{array}{l}\text { Recommended } \\
\text { in current } \\
\text { guidelines }\end{array}$ \\
\hline Alemtuzumab & & & $\mathrm{x}$ \\
Atezolizumab & $\mathrm{x}$ & $\mathrm{x}$ & $\mathrm{x}$ \\
Avelumab & $\mathrm{x}$ & $\mathrm{x}$ & $\mathrm{x}$ \\
Bevacizumab & $\mathrm{x}$ & & $\mathrm{x}$ \\
Blinatumomab & $\mathrm{x}$ & $\mathrm{x}$ & $\mathrm{x}$ \\
Brentuximab vedotin & $\mathrm{x}$ & $\mathrm{x}$ & $\mathrm{x}$ \\
Cetuximab & $\mathrm{x}$ & & $\mathrm{x}$ \\
Daratumumab & $\mathrm{x}$ & $\mathrm{x}$ & $\mathrm{x}$ \\
Denosumab & $\mathrm{x}$ & & $\mathrm{x}$ \\
Durvalumab & $\mathrm{x}$ & $\mathrm{x}$ & $\mathrm{x}$ \\
Elotuzumab & $\mathrm{x}$ & $\mathrm{x}$ & $\mathrm{x}$ \\
Gemtuzumab ozogamicin & & & \\
Ibritumomab tiuxetan & $\mathrm{x}$ & & \\
Ipilimumab & $\mathrm{x}$ & $\mathrm{x}$ & $\mathrm{x}$ \\
Necitumumab & $\mathrm{x}$ & $\mathrm{x}$ & \\
Nivolumab & $\mathrm{x}$ & $\mathrm{x}$ & $\mathrm{x}$ \\
Obinutuzumab & $\mathrm{x}$ & $\mathrm{x}$ & $\mathrm{x}$ \\
Ofatumumab & $\mathrm{x}$ & & $\mathrm{x}$ \\
Olaratumumab & $\mathrm{x}$ & $\mathrm{x}$ & $\mathrm{x}$ \\
Panitumumab & $\mathrm{x}$ & & $\mathrm{x}$ \\
Pembrolizumab & $\mathrm{x}$ & $\mathrm{x}$ & $\mathrm{x}$ \\
Pertuzumab & $\mathrm{x}$ & $\mathrm{x}$ & $\mathrm{x}$ \\
Ramucirumab & $\mathrm{x}$ & $\mathrm{x}$ & $\mathrm{x}$ \\
Rituximab & $\mathrm{x}$ & & $\mathrm{x}$ \\
Siltuximab & $\mathrm{x}$ & $\mathrm{x}$ & $\mathrm{x}$ \\
Trastuzumab & $\mathrm{x}$ & & $\mathrm{x}$ \\
Trastuzumab emtansine & $\mathrm{x}$ & $\mathrm{x}$ & $\mathrm{x}$ \\
\hline & & & \\
\hline
\end{tabular}

\section{Monoclonal Antibodies}

The gate-openers for monoclonal antibodies in oncology were rituximab and trastuzumab. The anti-CD20 antibody rituximab showed high remission rates in patients with relapsed and refractory follicular lymphoma $[5,6]$; the anti-HER 2 antibody trastuzumab induced remissions in women with metastatic HER2-overexpressing breast cancer [7]. Table 1 summarizes the monoclonal antibodies currently approved and/or recommended in Germany for use in oncology.

The biological targets are diverse. The spectrum ranges from inhibition of tumor cell activation through receptor blockade (e.g., trastuzumab, cetuximab), antiangiogenesis (e.g., bevacizumab, ramucirumab), immune checkpoint inhibition (ipilimumab, nivolumab, pembrolizumab), bispecific antibodies (blinatumomab), and others. More recently, antibody conjugates have been approved, e.g., trastuzumab emtansine and brentuximab vedotin.

The first biosimilars of monoclonal antibodies in oncology were approved in 2017. Blitzima ${ }^{\circledR}$ (Celltrion Healthcare Hungary Kft., Budapest, Hungary), Ritemvia $^{\circledR}$ (Celltrion), Rituzena ${ }^{\circledR}$ (Celltrion), Rixathon ${ }^{\circledR}$ (Sandoz, Kundl, Austria), Riximyo ${ }^{\circledR}$ (Sandoz), and Truxima ${ }^{\circledR}$
(Celltrion) are all rituximab biosimilars of Mabthera ${ }^{\circledR}$ (Hoffmann-La Roche, Basel, Switzerland), approved in oncology for patients with follicular lymphoma, diffuse large-cell B-cell lymphoma, and/or chronic lymphocytic leukemia $[8,9]$. Some of these biosimilars also got approval for rheumatoid diseases.

\section{Efficacy, Safety, and Benefit}

The most extensive comparative clinical studies with biosimilars including monoclonal antibodies have been performed in rheumatology [10]. They include randomized clinical trials with patient-relevant endpoints. Thus far, comparative studies between infliximab original and biosimilars as well as between etanercept original and biosimilars have revealed no significant differences in efficacy and safety. This also includes randomized trials on switching from the original to the biosimilar [11-13]. Importantly, the rate of induced antibodies against the biopharmaceutical did not differ.

Thus far, rituximab biosimilars have been studied in non-inferiority trials in patients with follicular lymphoma. Data from published clinical trials are summarized in table 2.

The same rituximab biosimilars are currently marketed in Europe under different names and with different indications (table 3 ).

Data on trastuzumab biosimilars are presented in a separate article in this issue, including data from randomized trials [14].

\section{Challenges}

Biosimilars are developed to have an analogous area of action as the reference drugs. However, in the underlying pharmaceutical manufacturing process, some degree of molecular variability is unavoidable. This effect is also prevalent in the production process of the primarily approved monoclonal antibodies, e.g., in different production batches or due to modifications in the production process. The risks of this 'biosimilarity' are:

- reduced efficacy

- improved efficacy (in this context, the term 'biobetter' is used)

- differences in immunogenicity, and

- side effects.

Due to the enormous requirements for the execution of a clinical study and the medical and economic need for biosimilars, these risks can never be investigated in full detail. 
Table 2. Published randomized clinical trials on rituximab biosimilars in oncology

\begin{tabular}{lllllll}
\hline Indication [ref.] & Control & New drug & $\begin{array}{l}\text { Patients, } \\
\mathrm{n}\end{array}$ & $\begin{array}{l}\text { Response rate, \% } \\
\text { (p value) }\end{array}$ & $\begin{array}{l}\text { Progression-free } \\
\text { survival, months } \\
\text { (p value) }\end{array}$ & $\begin{array}{l}\text { Overall survival, } \\
\text { months } \\
\text { (p value) }\end{array}$ \\
\hline Follicular lymphoma [22] & $\begin{array}{l}\text { chemotherapy } \\
+ \text { Mabthera }\end{array}$ & $\begin{array}{l}\text { chemotherapy } \\
+ \text { GP2013 }\end{array}$ & 629 & $\begin{array}{l}97.5 \text { vs. } 82.1 \\
\text { (not specified) }\end{array}$ & $\begin{array}{l}75.9 \text { vs. } 69.9 \\
(1.31)\end{array}$ & $\begin{array}{l}90.8 \text { vs. } 92.6 \\
(0.77)\end{array}$ \\
\hline Follicular lymphoma [23] & $\begin{array}{l}\text { chemotherapy } \\
\text { + Mabthera }\end{array}$ & $\begin{array}{l}\text { chemotherapy } \\
\text { + CT-P10 }\end{array}$ & 130 & $\begin{array}{l}92.6 \text { vs. } 97.0 \\
\text { (not specified) }\end{array}$ & \\
\hline
\end{tabular}

Table 3. Approval of rituximab biosimilars in the EU

\begin{tabular}{|c|c|c|c|c|c|c|c|}
\hline Brand name & Drug & Company & $\begin{array}{l}\text { Follicular } \\
\text { lymphoma }\end{array}$ & $\begin{array}{l}\text { Diffuse large-cell } \\
\text { B-cell lymphoma }\end{array}$ & $\begin{array}{l}\text { Chronic } \\
\text { lymphocytic } \\
\text { leukemia }\end{array}$ & $\begin{array}{l}\text { Rheumatoid } \\
\text { arthritis }\end{array}$ & Polyangiitis \\
\hline MabThera ${ }^{\circledR}$ & IDEC-C2B8 & Roche & $\mathrm{x}$ & $\mathrm{x}$ & $\mathrm{x}$ & $\mathrm{x}$ & $\mathrm{x}$ \\
\hline Blitzima $^{\circledR}$ & CT-P10 & Celltrion & $\mathrm{x}$ & $\mathrm{x}$ & $\mathrm{x}$ & & $\mathrm{x}$ \\
\hline Ritemvia ${ }^{\circledR}$ & CT-P10 & Celltrion & $\mathrm{x}$ & $\mathrm{x}$ & & & $\mathrm{x}$ \\
\hline Rituzena $^{\circledR}$ (Tuxella) & CT-P10 & Celltrion & $\mathrm{x}$ & $\mathrm{x}$ & $\mathrm{x}$ & & $\mathrm{x}$ \\
\hline Truxima $^{\circledR}$ & CT-P10 & Celltrion & $\mathrm{x}$ & $\mathrm{x}$ & $\mathrm{x}$ & $\mathrm{x}$ & $\mathrm{x}$ \\
\hline Rixathon $^{\circledR}$ & GP2013 & Sandoz & $\mathrm{x}$ & $\mathrm{x}$ & $\mathrm{x}$ & $\mathrm{x}$ & $\mathrm{x}$ \\
\hline Riximyo $^{\circledR}$ & GP2013 & Sandoz & $\mathrm{x}$ & $\mathrm{x}$ & & $\mathrm{x}$ & $\mathrm{x}$ \\
\hline
\end{tabular}

\section{Position of Scientific Medical Societies}

Scientific medical societies have to critically review the available data about efficacy, safety, and benefit of pharmaceuticals in oncology, especially in the context of recommendations in therapeutic guidelines. For generic drugs, this survey is mostly reduced to inform about potential differences in the approval status. For biosimilars, it must also be investigated if there are potentially increased risks due to the biological production process and related variability.

A position paper about biosimilars was published by the European Society for Medical Oncology (ESMO) in 2016 [15] and by the German Society of Hematology and Medical Oncology (Deutsche Gesellschaft für Hämatologie und Medizinische Onkologie, DGHO) in 2017 [16]. Both papers highlight the importance of biosimilars for the economic competitiveness of monoclonal antibodies. Biologicals held about $20 \%$ of the overall medical market in 2015 [17]; hence, the introduction of biosimilars offers substantial potential for possible savings. Previous experience suggests that by using biosimilars daily medical costs can be reduced by about $20-30 \%$. However, the acceptance of biosimilars seems to vary a lot and depend on various factors. Market analysis, for example on the use of infliximab in Germany in 2015 and 2016, revealed a broad variety in prescription behaviors [18]. By 2020, 12 of the most prescribed monoclonal antibodies will have lost patent protection [19]. While most of them are used in rheumatology, this fact has to also be faced for the oncological drugs rituximab, trastuzumab, and cetuximab (anti-epidermal growth factor receptor). At a time of exploding medical costs in Western health care systems, the introduction of biosimilars offers an economically relevant way of reducing costs. This fact may be even more important for medical care in less developed countries.

The ESMO statement emphasizes the need for stringent regulations and guidelines as declared by WHO, EMA, and the Food and Drug Administration (FDA) and warns against the use of non-comparable biologics or biomimics. These medical products received approval in countries with less stringent regulations and should not be used. The ESMO requires special qualifications for physicians prescribing biosimilars including extensive knowledge of the respective product information and the European Public Assessment Report (EPAR). Furthermore, physicians should inform patients about the use of a biosimilar and monitor these patients closely [15].

Active counselling of the patient by the treating physician seems to be the most important step in the information process. For this purpose, the DGHO provides special information material. In the informed consent process, the original compound should be named. The DGHO recommends the following steps for the first use of a biosimilar:

documentation of the prescribed drug and enhanced pharmacovigilance [16]. 
From a pharmaceutical point of view, biosimilars are considered to be an equivalent alternative to the original product. A certain molecular variability is permissible, as is the case for the original products. However, from a clinical point of view, some differences have to be carefully considered: a different kind of glycosylation of a biosimilar can lead to different receptor binding, resulting in a different effect and increased immunogenicity. Furthermore, these differences can induce a higher rate of neutralizing antibodies. These effects can be pronounced in long-term treatments that may include different prescribing physicians and result in exposure to several biologically similar substances.

In its position paper, the DGHO emphasized that the requirements for the prescription of biosimilars are not very different compared to other oncological drugs [20]. Data for newly approved drugs are often scarce as the patient population included in clinical studies is not the same as in clinical daily care [21]. It is well known that several side effects of a new drug will become visible only after its approval. Therefore, every prescription of a newly available/approved drug requires careful monitoring of efficacy and safety, especially in the context of comorbidities and comedications.

One important step forward in this context would be the implementation of independent registry data for newly approved medical drugs. Only with a standardized registration of real-life data after the approval of a new drug, safety in all indications and efficacy in indications for which randomized trials will never be possible can be investigated. This may be even more true for biosimilars for the reasons pointed out above.

\section{Disclosure Statement}

No conflicts of interest.

\section{References}

1 European Medicines Agency: Guideline on similar biological medicinal products, $23 \mathrm{Oct}$ 2014. www.ema.europa.eu/docs/en_GB/document_library/Scientific_guideline/2014/10/ WC500176768.pdf.

2 World Health Organization: Expert committee on biological standardization. Geneva, 17-21 October 2016. Guidelines on evaluation of monoclonal antibodies as similar biotherapeutic products (SBPs). www.who.int/ biologicals/expert_committee/mAb_SBP_GLECBS_review_adoption-2016.10.2611.7post_ECBS-Clean_Version.pdf.

$\checkmark 3$ Schellekens H: Biosimilar therapeutic agents: issues with bioequivalence and immunogenicity. Eur J Clin Invest 2004;34:797-799.

4 Casadevall N: Pure red cell aplasia and antierythropoietin antibodies in patients treated with epoetin. Nephrol Dial Transplant 2003; 18(suppl 8):viii37-41.

5 Maloney DG, Grillo-López AJ, White CA, et al: IDEC-C2B8 (rituximab) anti-CD20 monoclonal antibody therapy in patients with relapsed low-grade non-Hodgkin's lymphoma. Blood 1997;90:2188-2195.

-6 McLaughlin P, Grillo-López AJ, Link BK, et al: Rituximab chimeric anti-CD20 monoclonal antibody therapy for relapsed indolent lymphoma: half of patients respond to a fourdose treatment program. J Clin Oncol 1998; 16:2825-2833.

7 Baselga J, Tripathy D, Mendelsohn J, et al: Phase II study of weekly intravenous recombinant humanized anti-p185HER2 monoclonal antibody in patients with HER2/neuoverexpressing metastatic breast cancer. J Clin Oncol 1996;14:737-744.

8 European Medicines Agency: Truxima. $w w w$. ema.europa.eu/ema/index.jsp?curl=pages/ medicines/human/medicines/004112/human_med_002077.jsp.
9 European Medicines Agency: Meeting highlights from the Committee for Medicinal Products for Human Use (CJMP) 18-21 April 2017. www.ema.europa.eu/ema/index. jsp?curl=pages/news_and_events/ news/2017/04/news_detail_002732. jspermid=WC0b01ac058004d5c1.

10 Cohen S, Kay J: Biosimilars: implications for rheumatoid arthritis therapy. Curr Opin Rheumatol 2017;29:260-268.

11 Vencovsky J, Sylwestrzak A, Leszczyñski P, et al: A phase III, randomized, double-blind clinical study comparing SB4, an etanercept biosimilar, with etanercept reference product $\left(\right.$ Enbrel $^{\circledR}$ ) in patients with moderate to severe rheumatoid arthritis despite methotrexate therapy (52-week results); in 2015 ACR/ ARHP Annual Meeting Abstract Supplement. Arthritis Rheumatol 2015;67(suppl 10):abstr 2055.

12 Choe JY, Prodanovic N, Niebrzydowski J, et al: A randomised, double-blind, phase III study comparing SB2, an infliximab biosimilar, to the infliximab reference product Remicade in patients with moderate to severe rheumatoid arthritis despite methotrexate therapy. Ann Rheum Dis 2017;76:58-64.

13 Jørgensen K, Olsen I, Goll G, et al: LB15 - biosimilar infliximab (CT-P13) is not inferior to originator infliximab: results from the 52week randomized NOR-SWITCH trial. Abstract presented at the United European Gastroenterology (UEG) Week meeting 2016, 15-19 October, Vienna, Austria.

14 Rugo H, Barve A, Waller CF, et al.; Heritage Study Investigators: Effect of a proposed trastuzumab biosimilar compared with trastuzumab on overall response rate in patients with ERBB2 (HER2)-positive metastatic breast cancer: a randomized clinical trial. JAMA 2017;317:37-47.
15 Tabernero J, Vyas M, Giuliani R, et al: Biosimilars: a position paper of the European Society for Medical Oncology, with particular reference to oncology prescribers. ESMO Open 2017;1:e000142.

16 DGHO 2017: Positionspapier: Biosimilars von monoklonalen Antikörpern in der Medizinischen Onkologie. www.dgho.de/publikationen/stellungnahmen/gute-aerztliche-praxis/copy_of_biosimilars/Biosimilars\%20Positionspapier_FINAL.pdf/view.

17 Schwabe U, Paffrath D: ArzneiverordnungsReport 2016. www.wido.de/fileadmin/wido/ downloads/pdf_arzneimittel/wido_arz_ avr2016_pk_0916.pdf.

18 Flume M: Regional management of biosimilars in Germany. GaBI Journal 2017;5:125-127.

19 www.aerzteblatt.de/pdf/111/11/a452.pdf.

20 Freund M, Rottmann M, Wilhelm M: Medikamentöse Tumortherapie: Anordnung, Durchführung und Nachsorge, Onkopedia, 2012. www.onkopedia.com/de/onkopedial guidelines/medikamentoese-tumortherapieanordnung-durchfuehrung-und-nachsorge/@@view/html/index.html.

21 Frühe Nutzenbewertung neuer Arzneimittel in der Onkologie und Hämatologie, 2011-2016. Analysen und Impulse. Gesundheitspolitische Schriftenreihe der DGHO, Band 10, 2017.

22 Jurczak W, Ilidia M, Govindbabu KS, et al: A phase III efficacy and safety study of the proposed rituximab biosimilar GP2013 versus rituximab in patients with previously untreated advanced follicular lymphoma. Blood 2016;128:1809.

23 Coiffier B, Sancho J-M, Jurcza W, et al: Pharmacokinetic and safety of CT-P10, a biosimilar candidate to the rituximab reference product, in patients with newly diagnosed advanced stage follicular lymphoma (AFL). Blood 2016;128:1807. 